\title{
A non-linear model of hydrogen production by Caldicellulosiruptor saccharolyticus for diauxic-like consumption of lignocellulosic sugar mixtures
}

\author{
Johanna Björkmalm ${ }^{1,2^{*}}$, Eoin Byrne ${ }^{2}$, Ed W. J. van Niel ${ }^{2}$ and Karin Willquist ${ }^{1}$
}

\begin{abstract}
Background: Caldicellulosiruptor saccharolyticus is an attractive hydrogen producer suitable for growth on various lignocellulosic substrates. The aim of this study was to quantify uptake of pentose and hexose monosaccharides in an industrial substrate and to present a kinetic growth model of $C$. saccharolyticus that includes sugar uptake on defined and industrial media. The model is based on Monod and Hill kinetics extended with gas-to-liquid mass transfer and a cybernetic approach to describe diauxic-like growth.

Results: Mathematical expressions were developed to describe hydrogen production by C. saccharolyticus consuming glucose, xylose, and arabinose. The model parameters were calibrated against batch fermentation data. The experimental data included four different cases: glucose, xylose, sugar mixture, and wheat straw hydrolysate (WSH) fermentations. The fermentations were performed without yeast extract. The substrate uptake rate of C. saccharolyticus on single sugar-defined media was higher on glucose compared to xylose. In contrast, in the defined sugar mixture and WSH, the pentoses were consumed faster than glucose. Subsequently, the cultures entered a lag phase when all pentoses were consumed after which glucose uptake rate increased. This phenomenon suggested a diauxiclike behavior as was deduced from the successive appearance of two peaks in the hydrogen and carbon dioxide productivity. The observation could be described with a modified diauxic model including a second enzyme system with a higher affinity for glucose being expressed when pentose saccharides are consumed. This behavior was more pronounced when WSH was used as substrate.
\end{abstract}

Conclusions: The previously observed co-consumption of glucose and pentoses with a preference for the latter was herein confirmed. However, once all pentoses were consumed, C. saccharolyticus most probably expressed another uptake system to account for the observed increased glucose uptake rate. This phenomenon could be quantitatively captured in a kinetic model of the entire diauxic-like growth process. Moreover, the observation indicates a regulation system that has fundamental research relevance, since pentose and glucose uptake in C. saccharolyticus has only been described with $A B C$ transporters, whereas previously reported diauxic growth phenomena have been correlated mainly to PTS systems for sugar uptake.

Keywords: Caldicellulosiruptor saccharolyticus, Hydrogen, Kinetic growth model, Glucose uptake, Xylose uptake, Diauxic

\footnotetext{
${ }^{*}$ Correspondence: johanna.bjorkmalm@ri.se

1 Department of Energy and Circular Economy, RISE Research Institutes

of Sweden, PO Box 857, 50115 Borås, Sweden

Full list of author information is available at the end of the article
} 


\section{Background}

The need for renewable energy is ever increasing to tackle the major challenges of global warming, energy demand, and limited resources. According to statistics published by the International Energy Agency [1], just over 86\% of the Total Primary Energy Supply (TPES) in 2014 was produced from fossil resources, leaving a modest $14 \%$ originating from renewable energy sources. When putting these numbers in relation with the adopted Paris Agreement in 2015, targeting to keep the global average temperature increase below the $2{ }^{\circ} \mathrm{C}$ above pre-industrial levels [2], it is evident that actions need to be taken. There are, however, positive trends in that the supply of renewable energy sources has grown faster, with an average annual rate of $2.0 \%$ since 1990 , compared to the growth of the world TPES of $1.8 \%$ [1].

Hydrogen has the potential of becoming an important renewable energy carrier. Currently, hydrogen is widely used as a reducing agent in the chemical and food industry. However, using hydrogen as an energy carrier in sustainable applications is of great interest due to its potentially high efficiency of conversion to usable power, its low emissions of pollutants and high energy density [3]. Up to $96 \%$ of the world's hydrogen production is fossil based, i.e., natural gas, oil, and coal [4]. A sustainable alternative to the conventional methods for producing hydrogen is by biological methods, i.e., biohydrogen. There are four major categories in which production of biological hydrogen can be classified, namely: photofermentation of organic compounds by photosynthetic bacteria, biophotolysis of water using algae and cyanobacteria, bioelectrohydrogenesis, and fermentative hydrogen production, so-called dark fermentation, from organic wastes or energy crops $[5,6]$. The latter is the focus of this study, where various sugars present in, e.g., agricultural waste like wheat straw, can be fermented by microorganisms for hydrogen production. This also addresses the challenge of converting lignocellulosic biomass to renewable energy.

Lignocellulosic biomass has been previously described as "the most abundant organic component of the biosphere" with an annual production of $1-5 \cdot 10^{13} \mathrm{~kg}$ and, therefore, is an attractive substrate for biofuel production [7]. Lignocellulosic biomass primarily consists of cellulose (40-60\% CDW), hemicellulose (20-40\%), and lignin $(10-25 \%)$ [8]. Cellulose and hemicellulose can be enzymatically hydrolyzed into smaller sugar molecules.

The thermophilic microorganism Caldicellulosiruptor saccharolyticus is able to produce hydrogen from lignocellulosic biomass through dark fermentation and has previously shown the potential of producing hydrogen close to the maximum theoretical yield of $4 \mathrm{~mol}$ hydrogen per mol hexose [9-11]. C. saccharolyticus is cellulolytic and can utilize a broad range of di- and monosaccharides for hydrogen production [12]. Van de Werken et al. [13] showed that $C$. saccharolyticus coferments glucose and xylose as it lacks catabolite repression. VanFossen et al. [14] revealed that although $C$. saccharolyticus co-utilizes different sugars, it has a preference for some sugars over others. Xylose was discussed as a preferred sugar over glucose and is, therefore, utilized by the microorganism to a greater extent than glucose. However, the substrate uptake kinetics was not determined and a yeast extract (YE)-supplemented medium was used [13].

By developing a mathematical model for a biological process, it is possible to describe past and predict future performances as well as gaining a deeper understanding of the physiological mechanism behind the process. The aim of this study is to present a model that describes the growth of C. saccharolyticus on lignocellulosic sugar mixtures and how the uptake rate changes when the sugars are used simultaneously or individually. Similar kinds of models have been developed $[15,16]$; however, these models focus on single sugar uptake. The proposed model here builds on the one presented by Ljunggren et al. [15] by adding the consumption rates for each individual sugar in the sugar mixtures. Monod [17] first described the phenomenon of diauxic growth, where a microorganism is exposed to two substrates and first consumes the substrate that supports the most efficient growth rate. Several models have been developed in this area $[18,19]$ describing how to capture the subsequent uptake of sugars when multiple sugars are present. This phenomenon can be modeled using a cybernetic approach to whether a particular enzyme, needed for a specific sugar to be metabolized, is upregulated or not.

This paper describes the development of a substratebased uptake model using Monod-type kinetics including biomass growth, product formation, liquid-to-gas mass transfer, and enzyme synthesis with Hill kinetics, with $C$. saccharolyticus as model organism. The model presented in this paper takes into consideration the usage of different sugars, including hexoses, i.e., glucose, and pentoses, i.e., xylose and arabinose. The model describes the different sugar uptakes individually, exemplifying the rate at which each sugar is consumed when C. saccharolyticus grows on the sugar mixtures and on the individual sugars, respectively.

\section{Methods}

\section{Strains and cultivation medium}

Caldicellulosiruptor saccharolyticus DSM 8903 was obtained from the Deutsche Sammlung von Mikroorganismen und Zellkulturen (Braunschweig, Germany). Subcultivations were conducted in $250 \mathrm{~mL}$ serum flasks with $50 \mathrm{~mL}$ modified DSM 640 media [20]. The carbon source 
of each cultivation corresponded to that of the subsequent fermentor cultivation. The $1000 \times$ vitamin solution and modified SL-10 solution were prepared according to [20] and [21], respectively.

All bioreactor experiments used a modified DSM 640 medium with the exclusion of yeast extract according to Willquist and van Niel [20]. To quantify the kinetics of xylose and glucose uptake and the effect of when the sugars were mixed in pure and industrial medium, the growth and hydrogen production was monitored in four different cases, where the total sugar concentration in the medium was fixed to $10 \mathrm{~g} / \mathrm{L}$. Cultivations were performed using $10 \mathrm{~g} / \mathrm{L}$ glucose (Case 1 ), $10 \mathrm{~g} / \mathrm{L}$ xylose (Case 2 ), a sugar mixture (Case 3), and wheat straw hydrolysate (Case 4). In Case 4, a 9\% solution of wheat straw hydrolysate was used corresponding to approximately $10 \mathrm{~g} / \mathrm{L}$ total sugars. In Case 3, the sugar mixture contained pure sugars with the same concentration as the wheat straw hydrolysate $(6.75 \mathrm{~g} / \mathrm{L}$ glucose, $3.06 \mathrm{~g} / \mathrm{L}$ xylose, and $0.173 \mathrm{~g} / \mathrm{L}$ arabinose). The total sugar concentrations at the start of the fermentation included the sugar added as described above and the additional sugar added from the inoculum, which varied slightly in the different conditions. The starting sugar concentration was, therefore, as follows: Case 1, 12.11 $\pm 0.09 \mathrm{~g} / \mathrm{L}$ glucose; Case 2, $10.96 \pm 0.20 \mathrm{~g} / \mathrm{L}$ xylose; Case 3, 8.69 $\pm 0.12 \mathrm{~g} / \mathrm{L}$ glucose, $3.38 \pm 0.19 \mathrm{~g} / \mathrm{L}$ xylose, and $0.38 \pm 0.01 \mathrm{~g} / \mathrm{L}$ arabinose; Case $4,7.31 \pm 0.07 \mathrm{~g} / \mathrm{L}$ glucose, $3.36 \pm 0.06 \mathrm{~g} / \mathrm{L}$ xylose, and $0.34 \pm 0.00 \mathrm{~g} / \mathrm{L}$ arabinose.

\section{Fermentor setup}

Batch cultivations were performed in a jacketed, 3-L fermentor equipped with ADI 1025 Bio-Console and ADI 1010 Bio-Controller (Applikon, Schiedam, The Netherlands). A working volume of $1 \mathrm{~L}$ was used for cultivations and the $\mathrm{pH}$ was maintained at optimal conditions $6.5 \pm 0.1$ at $70{ }^{\circ} \mathrm{C}$ by automatic titration with $4 \mathrm{M} \mathrm{NaOH}$. The temperature was thermostatically kept at $70 \pm 1{ }^{\circ} \mathrm{C}$. Stirring was maintained at $250 \mathrm{rpm}$ and nitrogen was sparged through the medium at a rate of $6 \mathrm{~L} / \mathrm{h}$. Sparging was initiated $4 \mathrm{~h}$ after inoculation and was continued throughout the cultivation. A condenser cooled with water at $4{ }^{\circ} \mathrm{C}$ was utilized to prevent evaporation of the medium. Samples were collected at regular time intervals for monitoring of the optical density. The supernatant from each culture was collected and stored at $-20^{\circ} \mathrm{C}$ for further quantification of various sugars and organic acids. Gas samples were collected from the fermentor's headspace to quantify $\mathrm{H}_{2}$ and $\mathrm{CO}_{2}$. The sugar mixture and wheat straw hydrolysate experiments were done in triplicate. The individual sugar fermentations were done in biological duplicate.
A defined medium was autoclaved in each fermentor, while anoxic solutions of cysteine $\mathrm{HCl} \cdot \mathrm{H}_{2} \mathrm{O}(1 \mathrm{~g} / \mathrm{L})$, $\mathrm{MgCl}_{2} \cdot 6 \mathrm{H}_{2} \mathrm{O}(0.4 \mathrm{~g} / \mathrm{L})$, and carbon source $(\mathrm{s})$ were prepared separately and were added to the fermentor before inoculation. Just after inoculation, the fermentor was closed for $4 \mathrm{~h}$ to allow buildup of $\mathrm{CO}_{2}$ as previously described [20] necessary to initiate growth.

\section{Analytical methods}

Optical density was determined using an Ultraspec 2100 pro spectrophotometer (Amersham Biosciences) at $620 \mathrm{~nm}$. Sugars, organic acids, hydroxymethyl furfural (HMF), and furfural were detected using HPLC (Waters, Milford, MA, USA). For the quantification of organic acids, an HPLC equipped with an Aminex HPX-87H ion-exchange column (Bio-Rad, Hercules, USA) at $60{ }^{\circ} \mathrm{C}$ and $5 \mathrm{mM} \mathrm{H}_{2} \mathrm{SO}_{4}$ as mobile phase was used at a flow rate of $0.6 \mathrm{~mL} / \mathrm{min}$. Glucose, xylose, and arabinose quantification was conducted using an HPLC with a Shodex SP-0810 Column (Shodex, Japan) with water as a mobile phase at a flow rate of $0.6 \mathrm{~mL} / \mathrm{min}$. $\mathrm{CO}_{2}$ and $\mathrm{H}_{2}$ were quantified with a dual channel Micro-GC (CP-4900; Varian, Micro-gas chromatography, Middelburg, The Netherlands), as previously described [21].

\section{Mathematical model description}

The model developed for C. saccharolyticus in this study takes into account the kinetics of biomass growth, consumption of glucose, xylose and arabinose, and formation of the products acetate, hydrogen, and carbon dioxide. Furthermore, the model includes liquid-to-gas mass transfer of hydrogen and carbon dioxide as well as the equilibrium between carbon dioxide, bicarbonate $\left(\mathrm{HCO}_{3}{ }^{-}\right)$and carbonate $\left(\mathrm{CO}_{3}{ }^{2-}\right)$. The model is developed on a cmol basis. The formation of lactate was excluded to reduce the complexity of the model, as it constituted to less than $5 \%$ of the total product in the sugar mixture fermentations. In addition, inhibition due to high aqueous $\mathrm{H}_{2}$ concentration and high osmolarity was not included in the model to reduce the number of unknown parameters. This is motivated by the fact that the focus of this study is mainly on the consumption behavior of C. saccharolyticus on the different sugars.

The model is constructed with a similar nomenclature and setup as in the anaerobic digestion model no 1 (ADM1) described by Batstone et al. [22] and was implemented in MATLAB R2015b (Mathworks, USA). The following biochemical degradation reactions are the basis for the model (Eqs. 1, 2).

Biomass formation from sugar [23]: 


$$
\text { Sugar } \stackrel{\rho_{1}}{\rightarrow} Y_{X} \mathrm{CH}_{1.62} \mathrm{O}_{0.46} \mathrm{~N}_{0.23} \mathrm{~S}_{0.0052} \mathrm{P}_{0.0071} .
$$

Reaction 1 is not balanced, since there were elements in the fermentation medium that were not included in the model, i.e., cysteine. The value of the yield factor $Y_{X}$ is calculated from the data of the batch fermentations. It is assumed that nitrogen, sulfur, and phosphorus are in excess in the media and, therefore, are not included as separate entities in the mathematical model.

Sugar degradation to product formation by C. saccharolyticus in cmol:

$$
\mathrm{CH}_{2} \mathrm{O}+1 /{ }_{3} \mathrm{H}_{2} \mathrm{O} \stackrel{\rho_{2}}{\rightarrow} 2 /{ }_{3} \mathrm{CH}_{2} \mathrm{O}+1 /{ }_{3} \mathrm{CO}_{2}+2 /{ }_{3} \mathrm{H}_{2}
$$

\section{Model inputs and initial conditions}

The model requires a range of input variables. The lag time was determined by calculating the intersection point between the lag phase and the exponential phase when taking the natural logarithm of the biomass concentration over time, as illustrated by Swinnen et al. [24]. Since the lag phase is dependent on the culture status before the fermentation, which was not addressed in this study, it was excluded from the experimental data when the latter were compared to model data and for initial input values for the model. The start values of the unknown state variables are listed in Table 1. The constants used in the model are presented in Table 2.

\begin{tabular}{|c|c|c|c|c|c|c|}
\hline $\begin{array}{l}\text { State } \\
\text { variable }\end{array}$ & Description & $\begin{array}{l}\text { Case } 1 \\
\text { Glucose } \\
\text { fermentation }\end{array}$ & $\begin{array}{l}\text { Case } 2 \\
\text { Xylose } \\
\text { fermentation }\end{array}$ & $\begin{array}{l}\text { Case } 3 \\
\text { Sugar mix } \\
\text { fermentation }\end{array}$ & $\begin{array}{l}\text { Case } 4 \\
\text { Wheat straw } \\
\text { hydrolysate } \\
\text { fermentation }\end{array}$ & Unit \\
\hline Glu & Glucose concentration & 0.40 & - & 0.28 & 0.26 & $\mathrm{cmol} / \mathrm{L}$ \\
\hline Xyl & Xylose concentration & - & 0.36 & 0.10 & 0.11 & $\mathrm{cmol} / \mathrm{L}$ \\
\hline Ara & Arabinose concentration & - & - & 0.012 & 0.014 & $\mathrm{cmol} / \mathrm{L}$ \\
\hline X (Biomass) & Biomass concentration & 0.0013 & 0.00071 & 0.0016 & 0.0058 & $\mathrm{cmol} / \mathrm{L}$ \\
\hline Ac & Acetate concentration & 0.0012 & 0 & 0.0039 & 0.021 & $\mathrm{cmol} / \mathrm{L}$ \\
\hline $\mathrm{H}_{2, \mathrm{aq}}$ & $\mathrm{H}_{2}$ concentration (liquid phase) & 0 & 0 & 0 & 0 & M \\
\hline $\mathrm{CO}_{2, \mathrm{aq}}$ & $\mathrm{CO}_{2}$ concentration (liquid phase) & 0 & 0 & 0 & 0 & $\mathrm{cmol} / \mathrm{L}$ \\
\hline $\mathrm{CO}_{2, \mathrm{sol}}$ & $\begin{array}{l}\text { Concentration of all } \mathrm{CO}_{2} \text { ionic species } \\
\left(\mathrm{HCO}_{3}-\text { and } \mathrm{CO}_{3}^{2}-\right)\end{array}$ & 0 & 0 & 0 & 0 & $\mathrm{cmol} / \mathrm{L}$ \\
\hline $\mathrm{H}_{2, \mathrm{~g}}$ & $\mathrm{H}_{2}$ concentration (gas phase) & 0 & 0 & 0 & 0 & M \\
\hline $\mathrm{CO}_{2, \mathrm{~g}}$ & $\mathrm{CO}_{2}$ concentration (gas phase) & 0 & 0 & 0 & 0 & $\mathrm{cmol} / \mathrm{L}$ \\
\hline$E 2$ & Enzyme concentration & - & - & $1 e-7$ & $1 e-7$ & $\mathrm{cmol} / \mathrm{L}$ \\
\hline
\end{tabular}

Table 1 Start data of the unknown state variables in the model

\begin{tabular}{|c|c|c|c|}
\hline Constant & Value & Unit & Refs \\
\hline$V_{\text {liq }}$, liquid volume & 1 & $\mathrm{~L}$ & \\
\hline$V_{\text {gas' }}$ gas volume & 0.05 & $\mathrm{~L}$ & [15] \\
\hline $\mathrm{pH}$ & 6.5 & - & \\
\hline$k_{A B}$, acid base rate constant ${ }^{a}$ & 1e4 & - & \\
\hline$T$, temperature & 343.15 & K & \\
\hline$R$, ideal gas constant & 0.08206 & $\mathrm{~L} \mathrm{~atm} / \mathrm{K} / \mathrm{mol}$ & \\
\hline $\mathrm{KH}_{\mathrm{H}_{2}}$, Henry's constant $\mathrm{H}_{2}$ & $7.4 \mathrm{e}-9$ & $\mathrm{~mol} / \mathrm{L} / \mathrm{Pa}$ & \\
\hline $\mathrm{KH}_{\mathrm{CO}_{2}}$, Henry's constant $\mathrm{CO}_{2}$ & $2.7 e-7$ & $\mathrm{~mol} / \mathrm{L} / \mathrm{Pa}$ & \\
\hline$k_{\mathrm{L}} a_{\mathrm{CO}_{2}}$, volumetric mass transfer coefficient for carbon dioxide & $5.85 \cdot\left(\mathrm{N}_{2} / 6\right)^{0.46}$ & $h^{-1}$ & [15] \\
\hline $\mathrm{p} \mathrm{K}_{1}$, dissociation constant of reaction forming bicarbonate & 6.3 & - & \\
\hline $\mathrm{pK}_{2}$, dissociation constant of reaction forming carbonate & 10.25 & - & \\
\hline$\beta$, enzyme decay rate & 0.05 & $h^{-1}$ & [18] \\
\hline $\mathrm{N}_{2}$, stripping rate & 6 & $\mathrm{~L} / \mathrm{h}$ & \\
\hline
\end{tabular}

Table 2 Constants used in the model

\footnotetext{
a The acid-base reaction is considered to be in equilibrium at all times, which means that the reactions have infinitely fast reaction rates
} 
Mass balances for biomass growth, substrate consumption, and product formation in the liquid phase

The stoichiometric relationships and mass balances of the reactants and products present in the model are displayed in Table 3. The model is supplemented with an enzyme, $E 2$, and cybernetic variables $v$ and $u$ as in [18], where the former controls the activity of the enzyme and the latter is the fractional allocation of a critical resource for the synthesis of the enzyme. We hypothesize that initially, there is a first enzyme system present aiding the subsequent uptake of both hexose and pentose sugars, but with a preference for the pentoses (phase I). This transporter is only available as long as pentoses are present. After depletion of the pentoses, a second enzyme system, $E 2$, is synthesized allowing for uptake of the remaining hexose sugars by a second transporter (phase II). For the sake of convenience, we simplify the enzyme system, consisting of multiple proteins, using the word enzyme and using this abstraction also in the kinetic model.

The mass balance for the biomass, $X$, is dependent on the rate of substrate consumption $\rho$, with Monodtype kinetics, and on the biomass decay rate, which is described with first-order kinetics, where $r_{\mathrm{cd}}\left(\mathrm{h}^{-1}\right)$ is the cell death rate and $Y_{x}(\mathrm{cmol} / \mathrm{cmol})$ is the yield of biomass from total sugar (Table 3 ). A second glucose rate equation $\left(\rho_{\mathrm{Glu}, 2}\right)$ is added to describe the diauxic-like growth appearance in the sugar mixture. The rate of the glucose consumption, when the pentose sugars are depleted, is dependent on enzyme $E 2$. The rate of the enzyme synthesis, $\rho_{E}$, is based on Hill kinetics, as in [19], the decay rate of the enzyme is first-order kinetics, and the third term, $-1 \cdot E 2 \cdot \rho_{\mathrm{Glu}, 2}$, represents the dilution of the specific enzyme level as is described with kinetics similar to Hill, i.e., $E 2^{2}$. The parameters $k_{\mathrm{m}}$ and $k_{\mathrm{m}, 2}\left(\mathrm{~h}^{-1}\right)$ are the maximal uptake rates in phase I and phase II, respectively, and $K_{\mathrm{s}, \mathrm{glu}}, K_{\mathrm{s}, \mathrm{glu}, 2}, K_{\mathrm{s}, \mathrm{xyl}}, K_{\mathrm{s} \text {,ara, }}$ and $K_{s, E 2}(\mathrm{cmol} / \mathrm{L})$ are the affinity constants for the uptake of glucose, xylose, arabinose, and synthesis of enzyme E2, respectively. Finally, $\alpha$ is the enzyme synthesis rate $\left(\mathrm{h}^{-1}\right)$ and $\beta$ is the enzyme decay rate $\left(h^{-1}\right)$.

Acetate, hydrogen, and carbon dioxide are produced in the liquid phase. $Y_{\mathrm{ac}}(\mathrm{cmol} / \mathrm{cmol}), Y_{\mathrm{H}_{2}}(\mathrm{~mol} / \mathrm{cmol})$ and $Y_{\mathrm{CO}_{2}}(\mathrm{cmol} / \mathrm{cmol})$ represent the conversion yields of acetate, hydrogen, and carbon dioxide, respectively, from both hexose and pentose sugars. The conversion yields were fitted with experimental data from the batch fermentations. $Y_{X}$ was determined by the slope of the curve: total sugar vs biomass; here, only phase I was considered. $Y_{\mathrm{ac}}$ and $Y_{\mathrm{CO}_{2}}$ were determined by first taking the slope of the curves, total sugar vs acetate, and total sugar vs carbon dioxide, and then, the actual yields were calculated according to the following equation:

$$
Y_{\mathrm{Ac}}=\frac{Y_{\text {Ac, curve slope }}}{1-Y_{X}} .
$$

When $Y_{\mathrm{H}_{2}}$ was calculated the same way as in Eq. 3, it gave a too high conversion yield. To obtain a more accurate yield, the effects of liquid-to-gas mass transport were considered and $Y_{\mathrm{H}_{2}}$ was instead determined as follows:

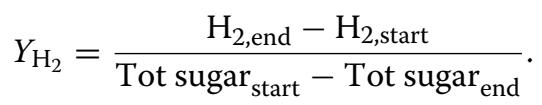

Table 3 Description of the model setup including mass balances for the sugars (glucose, xylose, and arabinose), enzyme

\begin{tabular}{|c|c|c|c|c|c|c|c|c|c|c|}
\hline \multirow[t]{2}{*}{ Phase I } & \multirow[t]{2}{*}{ Phase II } & \multicolumn{9}{|c|}{ Process $\downarrow$} \\
\hline & & Glu & Xyl & Ara & Ac & $\mathrm{H}_{2, \mathrm{aq}}$ & $\mathrm{CO}_{2, \mathrm{aq}}$ & $E 2$ & $x$ & Rate $(\rho, \mathrm{cmol} / \mathrm{L} / \mathrm{h})$ \\
\hline \multirow[t]{2}{*}{ Glu } & & -1 & & & $\left(1-Y_{X}\right) \cdot Y_{\text {ac }}$ & $\left(1-Y_{\chi}\right) \cdot Y_{\mathrm{H}_{2}}$ & $\left(1-Y_{X}\right) \cdot Y_{\mathrm{CO}_{2}}$ & & $Y_{x}$ & $\rho_{\mathrm{Glu}}=k_{\mathrm{m}} \cdot \frac{\mathrm{Glu}}{\mathrm{Glu}+K_{\mathrm{s}, \mathrm{glu}}} \cdot X \cdot v_{1}$ \\
\hline & Glu & -1 & & & $\left(1-Y_{\chi}\right) \cdot Y_{\mathrm{ac}}$ & $\left(1-Y_{X}\right) \cdot Y_{H_{2}}$ & $\left(1-Y_{\mathrm{X}}\right) \cdot Y_{\mathrm{CO}_{2}}$ & $-1 \cdot E 2$ & $Y_{x}$ & $\rho_{\mathrm{Glu}, 2}=k_{\mathrm{m}, 2} \cdot E 2 \cdot \frac{\mathrm{Glu}}{\mathrm{Glu}+K_{\mathrm{s}, \mathrm{glu}, 2}} \cdot X \cdot v_{2}$ \\
\hline Xyl & & & -1 & & $\left(1-Y_{X}\right) \cdot Y_{\text {ac }}$ & $\left(1-Y_{X}\right) \cdot Y_{H_{2}}$ & $\left(1-Y_{X}\right) \cdot Y_{\mathrm{CO}_{2}}$ & & $Y_{x}$ & $\rho_{\mathrm{xyl}}=k_{\mathrm{m}} \cdot \frac{\mathrm{xyl}}{\mathrm{xyl}+K_{\mathrm{s}, \mathrm{xyl}}} \cdot x \cdot v_{1}$ \\
\hline \multirow[t]{3}{*}{ Ara } & & & & -1 & $\left(1-Y_{\chi}\right) \cdot Y_{\mathrm{ac}}$ & $\left(1-Y_{\chi}\right) \cdot Y_{\mathrm{H}_{2}}$ & $\left(1-Y_{\chi}\right) \cdot Y_{\mathrm{CO}_{2}}$ & & $Y_{x}$ & $\rho_{\text {Ara }}=k_{\mathrm{m}} \cdot \frac{\text { Ara }}{\text { Ara }+K_{\text {s,ara }}} \cdot X \cdot v_{1}$ \\
\hline & Enzyme, E2 (synthesis) & & & & & & & 1 & & $\rho_{E}=\alpha \cdot \frac{\mathrm{Glu}^{n}}{\mathrm{Glu}^{n}+K_{\mathrm{s}, E 2}^{n}} \cdot X \cdot u$ \\
\hline & Enzyme, E2 (decay) & & & & & & & -1 & & $\rho_{\mathrm{dec}, E 2}=\beta \cdot E 2$ \\
\hline \multirow[t]{4}{*}{ Biomass (decay) } & Biomass (decay) & & & & & & & & -1 & $\rho_{\mathrm{dec}, X}=r_{\mathrm{cd}} \cdot X$ \\
\hline & & & & & & & & & & $v_{1}=\frac{\rho_{\mathrm{Xyl}}}{\max \left(\rho_{\mathrm{xy}} ; \rho_{\mathrm{Glu}, 2}\right)}$ \\
\hline & & & & & & & & & & $v_{2}=\frac{\rho_{\mathrm{Glu}, 2}}{\max \left(\rho_{\mathrm{xyl}} ; \rho_{\mathrm{Glu}, 2}\right)}$ \\
\hline & & & & & & & & & & $u=\frac{\rho_{\mathrm{Glu}, 2}}{\operatorname{sum}\left(\rho_{\mathrm{xyl}} ; \rho_{\mathrm{Glu}, 2}\right)}$ \\
\hline
\end{tabular}
E2, biomass, acetate, aqueous hydrogen, and aqueous carbon dioxide 


\section{Acid-base reactions}

The acid-base reaction considered in the model is that of carbon dioxide, bicarbonate, and carbonate formation. $\rho_{\mathrm{AB}, \mathrm{CO}_{2}}$ in Table 4 describes the rate of formation of bicarbonate and carbonate.

$\mathrm{CO}_{2 \text {,sol }}$ is the sum of the ionic species, $\mathrm{HCO}_{3}^{-}$and $\mathrm{CO}_{3}{ }^{2-}$ and Eq. 5 gives the differential equation for $\mathrm{CO}_{2, \text { sol }}$ :

$$
\frac{d \mathrm{CO}_{2, \mathrm{sol}}}{\mathrm{d} t}=\rho_{\mathrm{AB}, \mathrm{CO}_{2}} .
$$

\section{Liquid-to-gas mass transfer and mass balances for product formation}

Hydrogen and carbon dioxide are produced in the liquid phase and then transferred to the gas phase via liquid-togas mass transport. $\rho_{t, \mathrm{H}_{2}}$ describes the mass transfer rate of hydrogen and $\rho_{t, \mathrm{CO}_{2}}$ is the mass transfer rate of carbon dioxide (Table 5). $p_{\text {gas, } \mathrm{H}_{2}}$ and $p_{\text {gas, } \mathrm{CO}_{2}}$ (in atm then converted to $\mathrm{Pa}$ ) are the partial pressures of $\mathrm{H}_{2}$ and $\mathrm{CO}_{2}$, respectively.

The expression for the mass balances describing the gaseous products can be described as in Eqs. 6, 7, where $q_{\text {gas }}(\mathrm{L} / \mathrm{h})$ is the total gas flow, and $V_{\text {liq }}$ and $V_{\text {gas }}(\mathrm{L})$ are the liquid and the gas volumes, respectively:

$$
\begin{aligned}
& \frac{\mathrm{dH}_{2, \mathrm{~g}}}{\mathrm{~d} t}=\frac{V_{\text {liq }}}{V_{\text {gas }}} \cdot \rho_{t, \mathrm{H}_{2}}+\left(-\mathrm{H}_{2, \mathrm{~g}} \cdot \frac{q_{\text {gas }}}{V_{\text {gas }}}\right) \\
& \frac{\mathrm{dCO}_{2, \mathrm{~g}}}{\mathrm{~d} t}=\frac{V_{\text {liq }}}{V_{\text {gas }}} \cdot \rho_{t, \mathrm{CO}_{2}}+\left(-\mathrm{CO}_{2, \mathrm{~g}} \cdot \frac{q_{\text {gas }}}{V_{\text {gas }}}\right) .
\end{aligned}
$$

\section{Sensitivity analysis}

A sensitivity analysis can identify parameters that have great effect on the model output. The sensitivity analysis was done based on the OFAT approach, i.e., one-factorat-at-time [25]. The chosen parameter was altered with a factor $\delta$, as described in [26], to see the effect on the different state variable output result, as in the following equation:

$$
\Gamma_{i, j}=\frac{\left(y_{i}\left(\theta_{j}\right)-y_{i}\left(\theta_{j}+\delta \cdot \theta_{j}\right)\right) / y_{i}\left(\theta_{j}\right)}{\delta},
$$

where $\Gamma_{i, j}$ is the sensitivity of state variable $i$ with respect to model parameter $j$ in each timepoint of the Matlab simulation. Furthermore, $y_{i}\left(\theta_{j}\right)$ is the value of state variable $i$ in regard to parameter $j$ and $y_{i}\left(\theta_{j}+\delta \cdot \theta_{j}\right)$ is the value of state variable $i$ when parameter $j$ has been altered with a factor $\delta$. The parameters that were included in the sensitivity analysis were $k_{\mathrm{m}}, k_{\mathrm{m}, 2}, K_{\mathrm{s} \text {,glu }}, K_{\mathrm{s}, \mathrm{glu}, 2}, K_{\mathrm{s}, \mathrm{xyl}}, K_{\mathrm{s} \text {,ara }}$, $K_{\mathrm{s}, \mathrm{E} 2}, \alpha, n, r_{\mathrm{cd}}$ and $k_{\mathrm{L}} \mathrm{a}_{\mathrm{H} 2}$ and the state variables that were considered were Glu, Xyl, Ara, Ac, $X$, and $\mathrm{H}_{2}$. The presented sensitivity data of one parameter in regards to a specific state variable were calculated as the average of $\Gamma_{i, j}$

\section{Model calibration}

To get a better fit to the experimental data, the model parameters were calibrated using the knowledge that was revealed in the sensitivity analysis. This was done with the function lsqcurvefit in MATLAB which uses a least square method to find the right parameter value for a non-linear curve fitting by seeking to find coefficients $x$ that solve the problem in the following equation:

$\min _{x} \| F(x, x$ data $)-y$ data $\|_{2}^{2}=\min _{x} \sum_{i}\left(F\left(x, x \text { data }_{i}\right)-y \text { data }_{i}\right)^{2}$

\begin{tabular}{|c|c|c|c|c|}
\hline & Process & & & \\
\hline & $\mathrm{CO}_{2, \text { sol }}$ & $\mathrm{CO}_{2, \mathrm{aq}}$ & Rate $\left(\rho_{t, j}, \mathrm{cmol} / \mathrm{L} / \mathrm{h}\right)$ & \\
\hline $\mathrm{CO}_{2}$ acid-base & 1 & -1 & $\rho_{\mathrm{AB}, C \mathrm{CO}_{2}}=k_{\mathrm{AB}} \cdot\left(\mathrm{CO}_{2, \mathrm{aq}} \cdot\left(\frac{10^{-\mathrm{p} K_{1}}}{10^{-\mathrm{pH}}}+10^{-\mathrm{p} K_{1}} \cdot \frac{10^{-\mathrm{p} K_{2}}}{\left(10^{-\mathrm{pH}}\right)^{2}}\right)\right.$ & $-\mathrm{CO}_{2, \mathrm{sO}}$ \\
\hline
\end{tabular}

given the input data $x$ data and the observed output $y$ data, where $x$ data and $y$ data are matrices or vectors and

\begin{tabular}{|c|c|c|c|c|c|}
\hline & \multicolumn{5}{|c|}{ Process $\downarrow$} \\
\hline & $\mathrm{H}_{2, \mathrm{~g}}$ & $\mathrm{CO}_{2, \mathrm{~g}}$ & $\mathrm{H}_{2, \mathrm{aq}}$ & $\mathrm{CO}_{2, \mathrm{aq}}$ & Rate $\left(\rho_{t, j}, \mathrm{cmol} / \mathrm{L} / \mathrm{h}\right)$ \\
\hline $\mathrm{H}_{2}$ transfer & 1 & & -1 & & $\rho_{t, \mathrm{H}_{2}}=k_{L} a_{\mathrm{H}_{2}} \cdot\left(\mathrm{H}_{2, \mathrm{aq}}-p_{\mathrm{gas}, \mathrm{H}_{2}} \cdot \mathrm{KH}_{\mathrm{H}_{2}}\right)$ \\
\hline $\mathrm{CO}_{2}$ transfer & & 1 & & -1 & $\rho_{t, \mathrm{CO}_{2}}=k_{\mathrm{L}} a_{\mathrm{CO}_{2}} \cdot\left(\mathrm{CO}_{2, \mathrm{aq}}-p_{\mathrm{gas}, \mathrm{CO}_{2}} \cdot \mathrm{KH}_{\mathrm{CO}_{2}}\right)$ \\
\hline
\end{tabular}

Table 4 Kinetic rate equation for the acid-base reaction

Table 5 Liquid-to-gas mass transfer processes 
$F(x, x$ data $)$ is a matrix-valued or vector-valued function of the same size as $y$ data.

The lsqcurvefit function starts at $x 0$ and finds coefficient, i.e., parameter $x$, to best fit the non-linear function fun $(x, x$ data $)$ to the data $y$ data:

$$
x=\text { lsqcurvefit(fun, } x 0, x \text { data, } y \text { data). }
$$

The uncertainties of the calibrated parameters were assessed by calculating the confidence interval. This was done with the function nlparci in MATLAB which computes the 95\% confidence intervals for the non-linear least square parameters estimated.

\section{Results and discussion}

\section{Growth profiles on the various sugars}

The growth profiles of the single sugar experiments (glucose; Case 1 and xylose; Case 2), sugar mixture experiments (Case 3) and wheat straw hydrolysate experiments (Case 4) are presented in Fig. 1a-d. Glucose is consumed approx. two times faster when used as sole substrate
(Case 1) than in the sugar mixtures (Cases 3 and 4). Xylose, on the other hand, is consumed approx. two times slower when used as sole substrate and is completely consumed after approx. $60 \mathrm{~h}$ compared to around $20 \mathrm{~h}$ when co-fermented with other sugars (Cases 3 and 4; Fig. 1c, d). The highest production rate of acetate and hydrogen occurred around $20 \mathrm{~h}$ both in the sugar mixture and in the wheat straw hydrolysate fermentations. Lactate was formed just after 20 (Case 3) and $30 \mathrm{~h}$ (Case 4) reaching in total 0.015 and $0.014 \mathrm{cmol} / \mathrm{L}$, respectively.

The calculated lag phases differed for each experiment. The lag phases of the sugar mixture experiments ranged from 9 to $11 \mathrm{~h}$, whereas the lag phase of the wheat straw hydrolysate experiment was $4 \mathrm{~h}$. This observation could be correlated to the richer nutrient content of wheat straw than the defined sugar mixture medium. A similar observation was found by Pawar et al. [27]. The lag phase with glucose alone was $4 \mathrm{~h}$, but there was no lag phase with xylose alone. It is worth noticing though that it took more effort to initiate

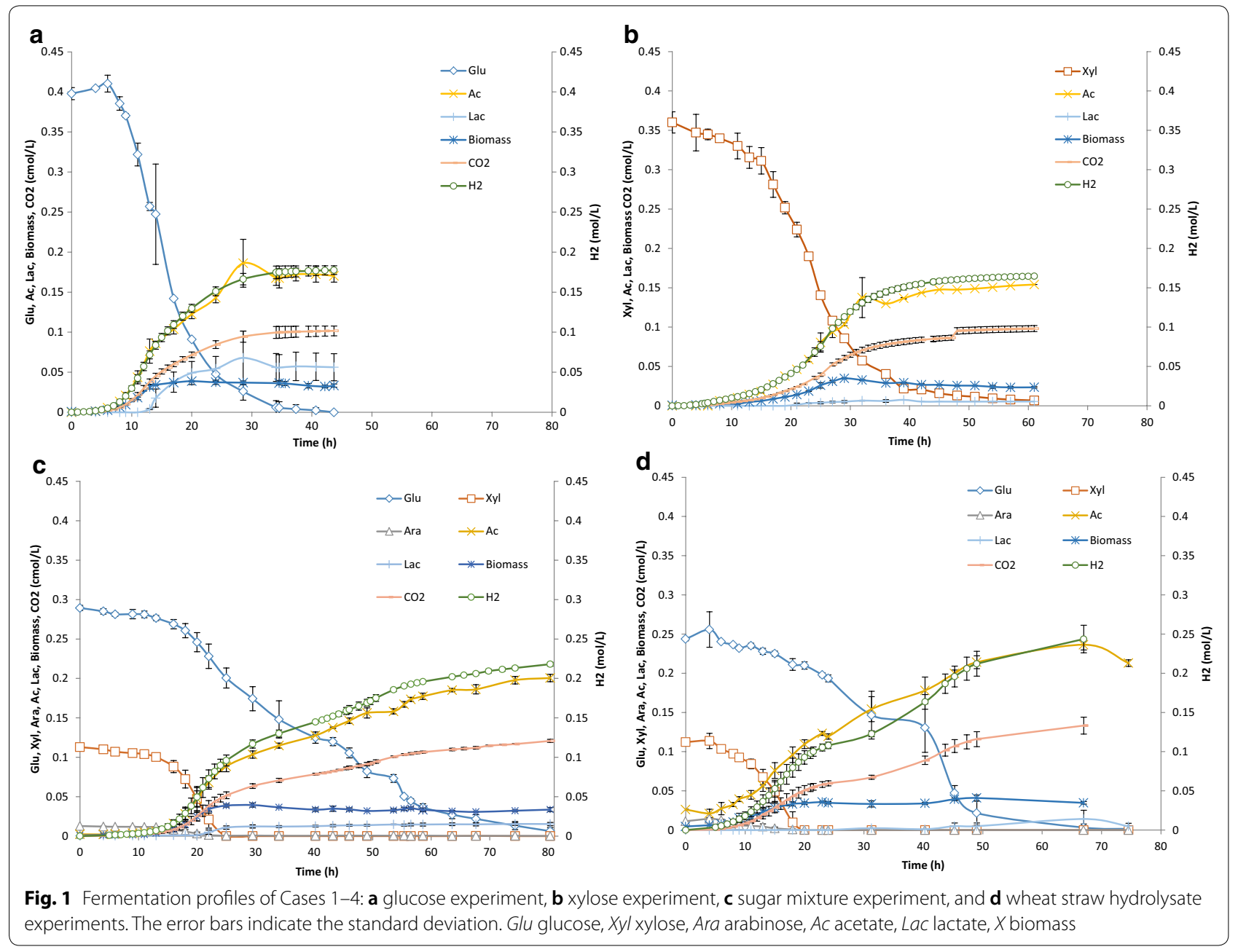


growth on xylose than on glucose as two out of four replicates failed, where none of the other experiments (Cases 1, 3, and 4) failed. This is due to that precautions are needed to start a culture on xylose in the absence of yeast extract, such as no sparging for several hours.

The profiles of the mixed sugars indicate a biphasic growth, where the uptake of glucose decreased after xylose was depleted, but then increased again (Fig. 1c, d). The two-phased sugar uptake was more pronounced in the wheat straw hydrolysate fermentations. The behavior can be further illustrated by the hydrogen productivity and $\mathrm{CO}_{2}$ productivity (Fig. 2a, b). This observation has, to our knowledge, not been reported for Caldicellulosiruptor previously, although the transcriptomics of multiple sugar uptake have been extensively studied [13, 14]. One possible reason for this could be that many multi-sugar experimental studies on this genus have been performed on a yeast extractsupplemented medium [3]. Because yeast extract itself partly supports growth [20], it possibly masks biphasic behavior. Moreover, the initial ratio of pentose/hexose
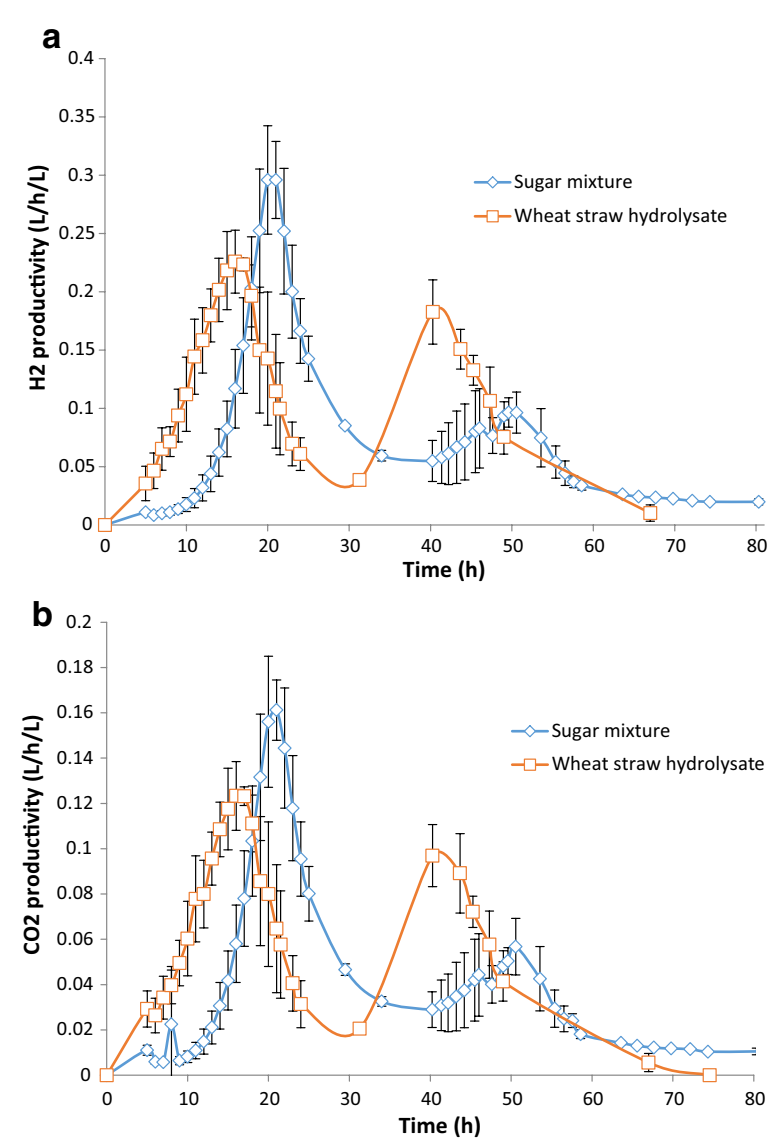

Fig. 2 a Hydrogen productivity and $\mathbf{b} \mathrm{CO}_{2}$ productivity in Cases 3 and 4, sugar mixture fermentation, and wheat straw hydrolysate fermentation, respectively sugars was higher in those studies [14] than in the WSH used in this study. Thus, after xylose was consumed, the culture adapted to a hexose-only medium, which initiated a second phase of growth.

The emerging pattern resembles a diauxic growth behavior, which was first described by Monod [17], and is characterized by two growth phases often separated with a lag period. This normally occurs in the presence of two carbon sources, where the preferred one is consumed first by the microorganism followed by the second after a lag period [28-30]. However, in the case of C. saccharolyticus, both pentose and hexose sugars are consumed simultaneously, albeit with a slight preference for the former. When the pentose sugars are depleted hexose consumption continues, but in Case 4 that happened with an increased rate (Table 8).

To quantify this behavior and investigate whether the theory of diauxic growth could be used to explain the observations, a kinetic model was developed consisting of two phases. In the phase I, glucose was consumed simultaneously with xylose and arabinose. Van de Werken et al. [13] concluded that growth on glucose and xylose mixtures as well as growth on the individual sugars all trigger transcription of the genes encoding a xylose-specific $A B C$ transport system. This supports our hypothesis that glucose, xylose, and arabinose were initially transported by the same uptake system. However, when xylose was depleted, phase II starts with a new uptake system being expressed that had a higher affinity for glucose, transporting glucose at an altered rate. It is relevant to observe, however, that diauxic growth behavior is generally considered to be related to PTS systems [31-33]. However, according to current knowledge, $C$. saccharolyticus only possesses $\mathrm{ABC}$ transport systems $[13,14]$. Still, it has been described that other transport systems can generate this diauxic growth profile. For example, in Streptomyces coelicolor and related species, the genes involved in carbon catabolite repression are PTS independent, and instead, glucose kinase is the main controlling enzyme [33].

\section{Determination of conversion yields}

The calculated conversion yields from the batch experiments differ from the stoichiometric yields (Table 6). To begin with, the single sugar fermentations the calculated yields are lower than the corresponding stoichiometric yields. This is in contrast to the yields calculated for the sugar mixture experiments, except for $Y_{\mathrm{ac}}$ that was slightly lower. The lower yield for acetate could be due to that part of the acetate, or rather acetyl-CoA, which is used as a building block for cell mass production [34].

The carbon balances attained in the model were 90 and $102 \%$ with start data from the sugar mixture experiments 
Table 6 Calculated carbon and redox balances plus the calculated yields of the four different experiments and their corresponding stoichiometric yields

\begin{tabular}{|c|c|c|c|c|c|c|}
\hline & $Y_{X}(\mathrm{cmol} / \mathrm{cmol})$ & $Y_{\mathrm{ac}}(\mathrm{cmol} / \mathrm{cmol})$ & $Y_{\mathrm{H}_{2}}(\mathrm{~mol} / \mathrm{cmol})$ & $Y_{\mathrm{CO}_{2}}(\mathrm{cmol} / \mathrm{cmol})$ & $\begin{array}{l}\text { Carbon } \\
\text { balance }\end{array}$ & Redox balance \\
\hline & $\begin{array}{l}\text { Yield, biomass } \\
\text { formation } \\
\text { from sugar }\end{array}$ & $\begin{array}{l}\text { Yield, acetate } \\
\text { formation } \\
\text { from sugar }\end{array}$ & $\begin{array}{l}\text { Yield, hydrogen } \\
\text { formation } \\
\text { from sugar }\end{array}$ & $\begin{array}{l}\text { Yield, carbon dioxide } \\
\text { formation from sugar }\end{array}$ & $(\%)$ & $(\%)$ \\
\hline Glucose experiments (Case 1) & 0.20 & 0.51 & 0.45 & 0.30 & 82 & 87 \\
\hline Xylose experiments (Case 2) & 0.12 & 0.50 & 0.47 & 0.31 & 80 & 81 \\
\hline Sugar mix experiments (Case 3) & 0.21 & 0.62 & 0.53 & 0.38 & 90 & 100 \\
\hline $\begin{array}{l}\text { Wheat straw hydrolysate } \\
\text { experiments (Case 4) }\end{array}$ & 0.18 & 0.68 & 0.67 & 0.44 & 107 & 90 \\
\hline Stoichiometrically & - & 0.67 & 0.67 & 0.33 & - & - \\
\hline
\end{tabular}

Table 7 Most sensitive parameters, i.e., sensitivity value $>1 \%$, listed in descending order for each state variable that was evaluated

\begin{tabular}{|c|c|c|}
\hline State variable & $\begin{array}{l}\text { Case } 3 \\
\text { Sugar mixture }\end{array}$ & $\begin{array}{l}\text { Case } 4 \\
\text { Wheat straw hydrolysate }\end{array}$ \\
\hline Glu & $k_{\mathrm{m}, 2}, a_{1} k_{\mathrm{m}}, r_{\mathrm{cd}}, k_{\mathrm{L}} a_{\mathrm{H}_{2}}, K_{\mathrm{s}, \mathrm{g} \mid \mathrm{u}, 2}$ & $k_{\mathrm{L}} a_{\mathrm{H}_{2}}, a, k_{\mathrm{m}, 2}, r_{\mathrm{cd}}, k_{\mathrm{m}}, K_{\mathrm{s}, \mathrm{glu}, 2}$ \\
\hline Xyl & $k_{\mathrm{L}} a_{\mathrm{H}_{2}}, k_{\mathrm{m}}, K_{\mathrm{s}, \text { ara }}, K_{\mathrm{s}, \mathrm{xyl}}$ & $k_{\mathrm{L}} a_{\mathrm{H}_{2}}, k_{\mathrm{m}}, K_{\mathrm{s}, \mathrm{xy} \mid}, K_{\mathrm{s}, \text { ara }}, K_{\mathrm{s}, E 2}$ \\
\hline Ara & $k_{\mathrm{s}, \mathrm{ara}}, k_{\mathrm{m}}, k_{\mathrm{L}} a_{\mathrm{H}_{2}}$ & $K_{\mathrm{s}, \text { ara }}$ \\
\hline$A c$ & - & - \\
\hline$x$ & - & - \\
\hline $\mathrm{H}_{2}$ & - & $k_{\mathrm{m}, 2}, \mathrm{a}$ \\
\hline
\end{tabular}

and the WSH experiments, respectively, which are equal or close to the values calculated from the experimental data, 90 and $107 \%$, respectively, Table 6 . The higher values in the carbon balance, i.e., $>100 \%$, for the WSH fermentations, could be due to that other carbon sources may be present, such as oligosaccharides, that are also converted to products giving a higher carbon and electron output.

\section{Sensitivity analysis}

Dynamic simulations using benchmark parameter values [15] showed discrepancies between the experimental results and the model predictions. To further improve the dynamic simulations, a sensitivity analysis was conducted to determine the most important parameters. This was done with start values both from the sugar mixture fermentations as well as from the wheat straw hydrolysate fermentations. The change, $\delta$, in the parameter value was set to $1 \%$ as in [35].

The sensitivity analysis allowed ranking of the parameters, which was useful for the model calibration. The most sensitive parameters, i.e., with a sensitivity value of $>1 \%$, in regard to each of the state variables are listed in Table 7. The state variables that were affected the most by a change in parameter value were Glu and Xyl. The sensitivities of the other parameters for the different state variables were less than $1 \%$.

\section{Parameter calibration}

The sensitivity analysis served as a basis for the parameter calibration. The model was calibrated with data from the four different batch experiments, Cases 1-4. Start values of the state variables were taken from the experimental data (Table 1), and initial parameter values, i.e., benchmark values, were taken from the literature [15] or guesstimated, e.g., by manually fitting the curves of the data points. The calibrated parameters together with a confidence interval of $95 \%$ are given in Table 8 . Some of the parameters were graphically calibrated and, therefore, are without a confidence interval. The simulations with start data from the single glucose and xylose fermentations were carried out without the diauxic-like growth additions; thus, only phase I was applied.

The $k_{\mathrm{m}}$ values for Cases 3 and 4 describe the maximal simultaneous uptake rates of glucose, xylose, and arabinose (Table 8), and they are modeled with the same value for all the sugars in phase I. However, the $K_{\mathrm{s}}$ values for glucose in phase I, $K_{\mathrm{s}, \mathrm{glu}}$, are higher than the $K_{\mathrm{s}}$ values for xylose, $K_{\mathrm{s}, \mathrm{xy}}$, which indicates a lower affinity for glucose in phase I, since xylose is present and preferred. Moreover, $K_{\mathrm{s}, \mathrm{glu}}$ in Case 4 is 18 times higher compared to $K_{\mathrm{s}, \mathrm{glu}, 2}$ and compared to $K_{\mathrm{s}, \mathrm{glu}}$ in Case 3. One explanation is the greater affinity for xylose in phase I and another possible explanation is that $K_{\mathrm{s}, \mathrm{glu}}$ in Case 4 also includes an inhibition term due to the characteristics of the wheat straw hydrolysate media, e.g., Eq. 11:

$$
K_{\mathrm{s}, \mathrm{glu}}=K_{\mathrm{s} \text {,glu, real }} \cdot I \text {, }
$$


Table 8 Parameters calibrated to experimental data

\begin{tabular}{|c|c|c|c|c|c|}
\hline Parameter & $\begin{array}{l}\text { Benchmark value } \\
\text { derived from [15] }\end{array}$ & $\begin{array}{l}\text { Case } 1 \\
\text { Glucose simulation }\end{array}$ & $\begin{array}{l}\text { Case } 2 \\
\text { Xylose simulation }\end{array}$ & $\begin{array}{l}\text { Case } 3 \\
\text { Sugar mixture simulation }\end{array}$ & $\begin{array}{l}\text { Case } 4 \\
\text { Wheat straw } \\
\text { hydrolysate } \\
\text { simulation }\end{array}$ \\
\hline$k_{m^{\prime}}$ maximal uptake rate $\left(h^{-1}\right)$ & 0.35 & - & $1.58( \pm 0.042)$ & $0.54( \pm 0.012)$ & $0.44( \pm 0.023)$ \\
\hline $\begin{array}{l}k_{m, 2}, \text { maximal uptake rate when } \\
\quad x y l o s e=0\left(h^{-1}\right)\end{array}$ & 0.35 & $2.4( \pm 0.15)$ & - & $0.54( \pm 0.018)$ & $1.26( \pm 0.11)$ \\
\hline $\begin{array}{l}K_{\mathrm{s}, \mathrm{glu}} \text {, affinity constant, glucose } \\
(\mathrm{cmol} / \mathrm{L})\end{array}$ & 0.00029 & $0.01^{\mathrm{a}}$ & - & $0.01^{\mathrm{a}}$ & $0.18( \pm 0.043)^{b}$ \\
\hline $\begin{array}{l}K_{\mathrm{s}, \mathrm{glu}, 2,} \text { affinity constant 2, glucose } \\
(\mathrm{cmol} / \mathrm{L})\end{array}$ & - & - & - & $0.01^{\mathrm{a}}$ & $0.01^{\mathrm{a}}$ \\
\hline $\begin{array}{l}K_{\text {s,xyly }} \text { affinity constant, xylose } \\
(\mathrm{cmol} / \mathrm{L})\end{array}$ & - & - & $0.0002^{\mathrm{a}}$ & $0.0002^{\mathrm{a}}$ & $0.0002^{\mathrm{a}}$ \\
\hline $\begin{array}{l}K_{\mathrm{s}, \text { ara }} \text { affinity constant, arabinose } \\
(\mathrm{cmol} / \mathrm{L})\end{array}$ & - & - & - & $0.026( \pm 0.004)$ & $0.034( \pm 0.0077)$ \\
\hline $\begin{array}{l}K_{\mathrm{s}, E 2,} \text { affinity constant enzyme, E2 } \\
(\mathrm{Cmol} / \mathrm{L})\end{array}$ & - & - & - & $0.001^{\mathrm{a}}$ & $0.001^{\mathrm{a}}$ \\
\hline a, enzyme synthesis rate $\left(\mathrm{h}^{-1}\right)$ & - & - & - & $0.6^{\mathrm{a}}$ & $0.64( \pm 0.085)$ \\
\hline$n$, Hill coefficient & - & - & - & $2^{\mathrm{a}}$ & $2^{\mathrm{a}}$ \\
\hline$r_{c d}$, cell death rate $\left(h^{-1}\right)$ & 0.014 & $0.0027^{\mathrm{a}}$ & $0.0027^{\mathrm{a}}$ & $0.027^{\mathrm{a}}$ & $0.027( \pm 0.0039)$ \\
\hline $\begin{array}{l}k_{\llcorner} a_{\mathrm{H}_{2}} \text {, volumetric mass transfer } \\
\text { coefficient for hydrogen }\left(\mathrm{h}^{-1}\right)\end{array}$ & 0.26 & $0.44^{\mathrm{a}}$ & $0.44^{\mathrm{a}}$ & $0.44( \pm 0.085)$ & $0.44^{\mathrm{a}}$ \\
\hline \multicolumn{2}{|c|}{$Y_{\mathrm{H}_{2}}$, yield, hydrogenformationfromsugar } & n.c. & n.c. & 0.58 & n.c. \\
\hline
\end{tabular}

Confidence interval 95\% (Cl, 95\%) is given for those parameters which have been fitted numerically

n.c. not calibrated, but the values calculated from the experimental data were used (Table 6)

a Graphically calibrated

b This value possibly also includes an inhibition factor I

where $I$ represents a competitive inhibition, Eq. 12:

$$
I=1+\frac{S_{I}}{K_{I}}
$$

with $S_{I}$ the concentration of the inhibitor and $K_{I}$ the inhibition parameter. This is possibly due to unknown inhibiting compounds in the wheat straw hydrolysate or other factors that inhibit glucose uptake in phase I in Case 4. The reason behind the competitive inhibition has not been identified, but we hypothesize the presence of oligosaccharides that might be preferably taken up instead of glucose. However, these sugars were not quantified in the HPLC analysis of WSH.

The $k_{\mathrm{m}, 2}$ value for Case 4 is $50 \%$ lower than the corresponding value for the glucose uptake rate in Case 1. One explanation for this is that the enzymes involved in the sugar uptake in Case 4 take some time to be synthesized making glucose consumption slower in the WSH compared to the single glucose fermentation. Again, the presence of inhibiting compounds or competitive oligosaccharides could further slow down the glucose uptake rate.

Furthermore, the results show that on single sugars and mineral medium, glucose uptake is approximately
Table 9 Maximal specific growth rates, $\mu_{\max }$ calculated from $k_{\mathrm{m}}, k_{\mathrm{m}, 2}$, and $Y_{x}$ values

\begin{tabular}{lll}
\hline Maximal specific growth rate $\left(\boldsymbol{\mu}_{\mathbf{m a x}} \mathbf{h}^{\mathbf{- 1}}\right)$ & Phase I & Phase II \\
\hline Glucose (Case 1) & 0.22 & - \\
Xylose (Case 2) & 0.13 & - \\
Sugar mixture (Case 3) & 0.33 & 0.11 \\
Wheat straw hydrolysate (Case 4) & 0.24 & 0.23 \\
\hline
\end{tabular}

$35 \%$ faster than xylose uptake (Table 8). Moreover, growth of C. saccharolyticus on glucose is approx. $40 \%$ faster than on xylose (Table 9). This outcome contradicts the previous results on these two sugars in media supplemented with yeast extract (YE), where growth is faster on xylose than on glucose [13, 14]. An explanation for this observation could be that $C$. saccharolyticus needs other sugars (present in YE) to grow optimal on xylose. Indeed, when both sugars are present the growth on xylose is stimulated by the co-uptake of glucose. The stoichiometric relationship of glucose-toxylose uptake rate $\rho$ (Glucose): $\rho$ (Xylose) was affected by the media used and is approximately 0.7 and 0.3 in phase I for growth on defined sugar mixture and wheat 
straw medium, respectively (data used from Fig. 1). Until xylose is depleted, the total glucose, xylose, and arabinose conversion rates, i.e., $0.54 .3 \mathrm{~h}^{-1}$, are similar to that of xylose conversion in the absence of glucose, i.e., $1.58 \mathrm{~h}^{-1}$. This observation is supported by other studies with $C$. saccharolyticus using different sugar mixtures both with and without YE, e.g. in Willquist [36]. Xylose uptake increases if a small concentration of glucose is present or if either the fermentor is sparged with $\mathrm{CO}_{2}$ instead of $\mathrm{N}_{2}$ gas or closed, to allow buildup of $\mathrm{HCO}_{3}{ }^{-}$in the reactor.

\section{Model prediction}

Comparison between the model and experimental results for the combined sugars is depicted in Table 10, and Figs. 3 and 4. The results show that a diauxic-like behavior model simulates well the experimental data of C. saccharolyticus when grown on mixtures of pentose and hexose sugars. Without the addition of a second enzyme equation as well as cybernetic variables controlling the upregulation of the enzyme, the experimental data could not be simulated.

Table 10 shows the fitting between the experimental data and the model simulation displaying the regression analysis values. It is clear that the model is well able to describe the consumption of the different sugars as well as biomass growth, acetate formation, and accumulation of hydrogen in Cases 3 and 4. The model, without the diauxic-like additions, was better at describing the individual xylose fermentations (Case 2), rather than the individual glucose fermentations (Case 1) when it comes to biomass growth and hydrogen production (Table 10).
The model only predicts a small second peak in hydrogen productivity compared to the data of the defined sugar mixture fermentations (Fig. 3g). However, the model succeeds in describing the diauxic-like behavior of the hydrogen productivity profile in the wheat straw hydrolysate fermentations (Fig. $4 \mathrm{~g}$ ). The uptake of the three sugars as well as the formation of acetate is well described by the model, both for Cases 3 and 4 (Figs. 3a-d, $4 a-d$ ).

According to the simulation, the enzyme (used to describe the diauxic behavior) concentration is very low, close to zero, in the beginning, and when phase I ends, the enzyme synthesis starts and the concentration increases up to a peak, where it begins decreasing just before $t=60 \mathrm{~h}$ in Case 3 and somewhat earlier in Case 4 (Figs. 3f, 4f). The enzyme synthesis is dependent on the biomass concentration, which is why it follows the behavior of the latter. The two biomass growth phases are clearly displayed in Case 4 and expressed by the model (Fig. 4e), where a first growth phase takes place between 0 and $20 \mathrm{~h}$ and a second growth phase between 20 and $45 \mathrm{~h}$. The phenomenon with two growth phases is characteristic for diauxic growth behavior as described in various literatures on the topic [18, 28, 37].

The hydrogen productivity profile, both in Cases 3 and 4 , is a bit delayed in the model (Figs. $3 \mathrm{~g}, 4 \mathrm{~g}$ ). This could be due to a slight underestimation of the $k_{\mathrm{L}} a_{\mathrm{H}_{2}}$ value. The benchmark $k_{\mathrm{L}} a_{\mathrm{H}_{2}}$ value used, from Ljunggren et al. [15], was later on calibrated against experimental data resulting in a higher value (Table 8). Still, the mass transfer seems to be less efficient in the model not being able to fully describe the experimental data.

Table $10 R^{2}$ values to describe the fit between experimental data and model simulation

\begin{tabular}{|c|c|c|c|c|}
\hline State variable & Glucose (Case 1) & Xylose (Case 2) & Sugar mixture (Case 3) & $\begin{array}{l}\text { Wheat straw } \\
\text { hydrolysate (Case } \\
\text { 4) }\end{array}$ \\
\hline Glu & 0.96 & - & 0.99 & 0.97 \\
\hline Xyl & - & 0.98 & 0.99 & 0.99 \\
\hline Ara & - & - & 0.99 & 0.95 \\
\hline$x$ & 0.46 & 0.86 & 0.92 & 0.90 \\
\hline Ac & 0.91 & 0.99 & 0.99 & 0.99 \\
\hline $\mathrm{H}_{2}$ accumulated & 0.74 & 0.99 & 0.99 & 0.98 \\
\hline
\end{tabular}

\footnotetext{
(See figure on next page.)
}

Fig. 3 Sugar mixture experimental data and model simulation. a Glucose (cmol/L) data and model; b xylose data and model (cmol/L); c arabinose $(\mathrm{cmol} / \mathrm{L})$ data and model; $\mathbf{d}$ acetate $(\mathrm{cmol} / \mathrm{L})$ data and model; e biomass $(\mathrm{cmol} / \mathrm{L})$ data and model; $\mathbf{f}$ enzyme, E2 $(\mathrm{cmol} / \mathrm{L})$ data and model; $\mathbf{g}$ hydrogen productivity $(\mathrm{L} / \mathrm{h} / \mathrm{L})$ data and model; and $\mathbf{h}$ hydrogen accumulated (mol/L) data and model. Exp. data E28 experimental data E28, Exp. data E29 experimental data E29, and Exp. data E30 experimental data E30 


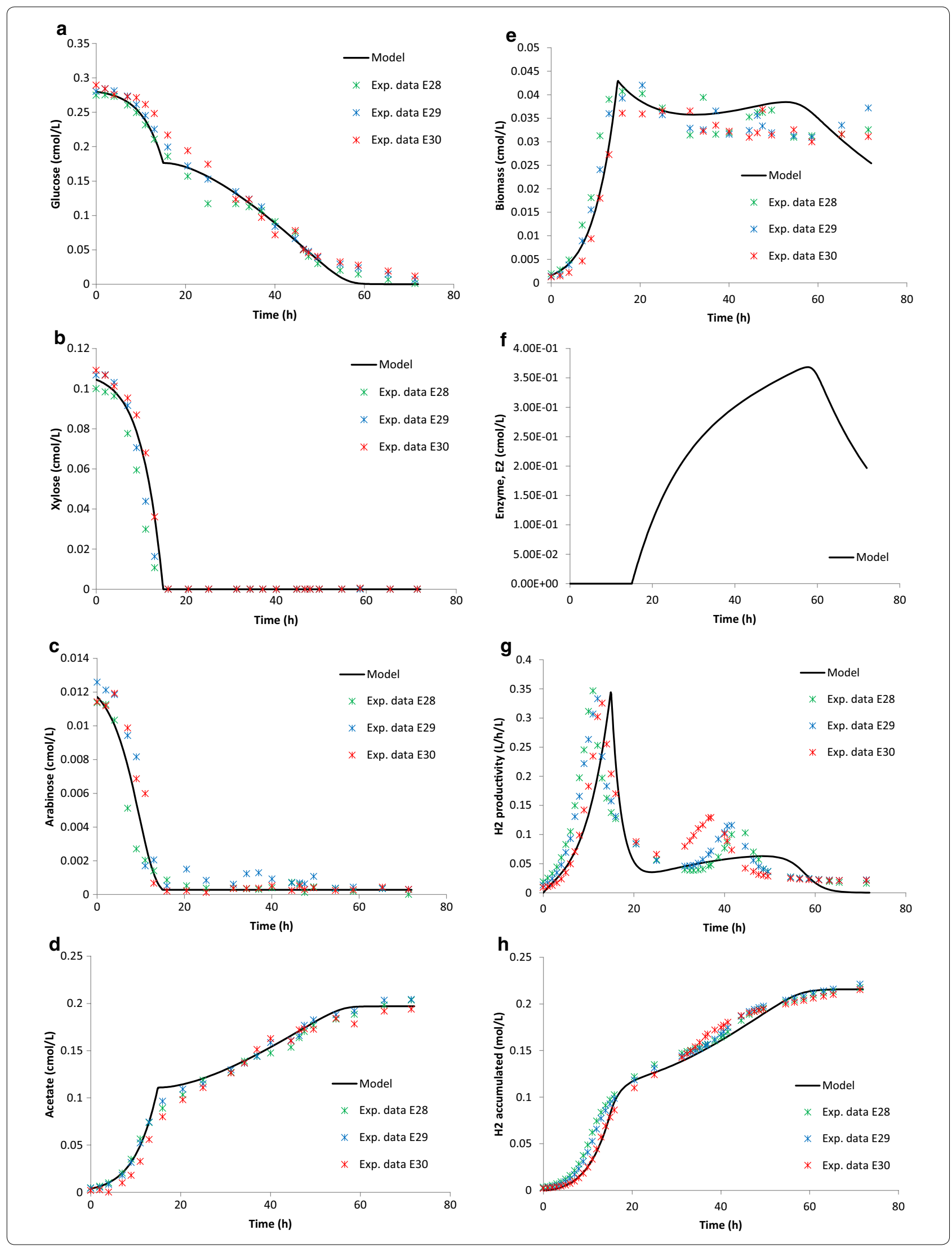




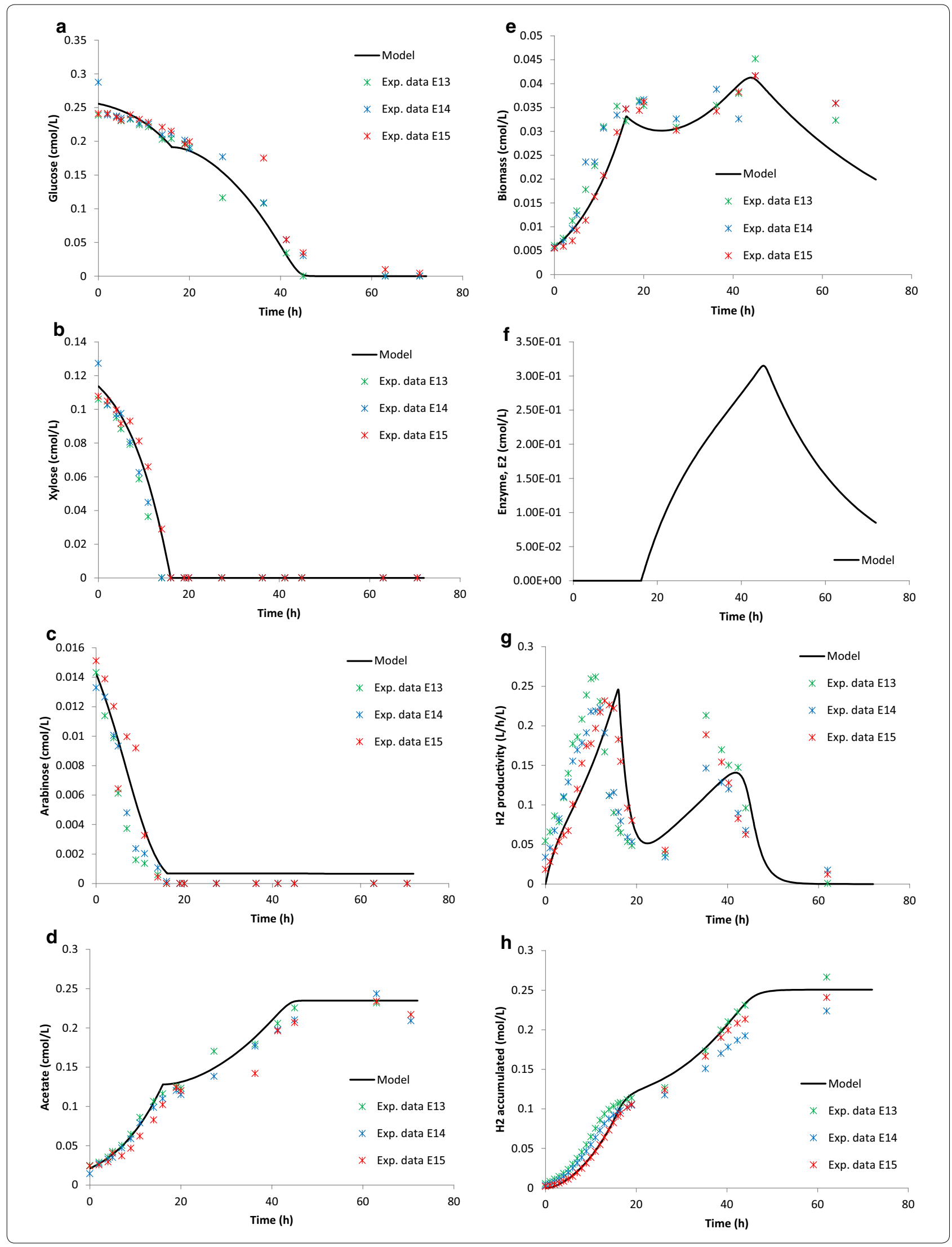




\section{(See figure on previous page.)}

Fig. 4 Wheat straw hydrolysate experimental data and model simulation. a Glucose (cmol/L) data and model; b xylose data and model (cmol/L); c arabinose $(\mathrm{cmol} / \mathrm{L})$ data and model; $\mathbf{d}$ acetate $(\mathrm{cmol} / \mathrm{L})$ data and model; e biomass (cmol/L) data and model; f enzyme, E2 ( $\mathrm{cmol} / \mathrm{L})$ data and model; $\mathbf{g}$ hydrogen productivity $(\mathrm{L} / \mathrm{h} / \mathrm{L})$ data and model; and $\mathbf{h}$ hydrogen accumulated (mol/L) data and model. Exp. data E13 experimental data E13, Exp. dataE14 experimental data E14 and Exp. dataE15 experimental data E15

\section{Conclusions}

The outcome of this study revealed that in batch mode, C. saccharolyticus ferments (un)defined sugar mixtures via different growth phases in a diauxic-like manner. This behavior could be successfully simulated with a kinetic growth model with substrate-based Monod-type kinetics and enzyme synthesis using Hill kinetics together with cybernetic variables to control the upregulation of the enzyme. The model was able to predict the behavior of growth on sugar mixtures both in a defined medium and in wheat straw hydrolysate medium. The model supported the following sequence: xylose is the preferred substrate, but glucose is taken up simultaneously, possibly with the same transporter. After xylose is depleted, glucose is further taken up with a newly induced transporter system, leading to a second hydrogen productivity peak. We further conjecture that this diauxic-like pattern might appear in defined media not containing complex nutrient mixtures, such as yeast extract, as the latter might reduce the edge of the transition point from dominant xylose uptake to dominant glucose uptake by C. saccharolyticus. Future studies should aim at investigating how the various uptake mechanisms in C. saccharolyticus act and contribute to the phenomena described in this study. In addition, a further developed model, verifying the values of several kinetic parameters, including separate maximal uptake rates for the different sugars in the sugar mixture as well as inhibition functions, would improve the applicability of this model for industrial processes.

\footnotetext{
Authors' contributions

JB: data analysis, calculations, model development, and manuscript writing. EB: planning and execution of the fermentation experiments, HPLC and GC analyses, and manuscript writing. EvN: supervision of fermentation, analysis, and manuscript writing. KW: supervision of modeling, analysis and fermentation, and manuscript writing. All authors contributed to revision of the manuscript and approved the text, figures, and tables for submission. All authors read and approved the final manuscript.
}

\section{Author details}

${ }^{1}$ Department of Energy and Circular Economy, RISE Research Institutes of Sweden, PO Box 857, 50115 Borås, Sweden. ${ }^{2}$ Division of Applied Microbiology, Lund University, PO Box 124, 22100 Lund, Sweden.

\section{Acknowledgements}

The authors acknowledge the Swedish Energy Agency for the financial support of this work under "Metanova" Project No. 31090-2.

\section{Competing interests}

The authors declare that they have no competing interests.

\section{Availability of data and materials}

All data generated or analyzed during this study are included in this article. If additional information is needed, please contact the corresponding author.

\section{Consent for publication}

Not applicable.

Ethics approval and consent to participate

Not applicable.

\section{Funding}

The study was funded by the Swedish Energy Agency whom did not participate in the execution of the study or in the manuscript writing.

\section{Publisher's Note}

Springer Nature remains neutral with regard to jurisdictional claims in published maps and institutional affiliations.

Received: 24 January 2018 Accepted: 12 June 2018

Published online: 22 June 2018

\section{References}

1. International Energy Agency. Renewables information 2017: overview. http://www.iea.org/publications/freepublications/publication/Renew ablesInformation20170verview.pdf. Accessed 10 Jan 2018.

2. United Nations. Adoption of the Paris Agreement. 2015. http://unfccc.int/ resource/docs/2015/cop21/eng/l09r01.pdf. Accessed 31 May 2017.

3. Pawar SS, van Niel EWJ. Thermophilic biohydrogen production: how far are we? Appl Microbiol Biotechnol. 2013;97(18):7999-8009. https://doi. org/10.1007/s00253-013-5141-1.

4. Press RJ, Santhanam KSV, Miri MJ, Bailey AV, Takacs GA. Introduction to hydrogen technology. 1st ed. Hoboken: Wiley; 2008.

5. van Niel EWJ. Biological processes for hydrogen production. In: Hatti-Kaul R, Mamo G, Mattiasson B, editors. Anaerobes in biotechnology. Berlin: Springer International Publishing; 2016. p. 155-93.

6. Das D, Veziroglu TN. Advances in biological hydrogen production processes. Int J Hydrogen Energy. 2008;33(21):6046-57. https://doi. org/10.1016/j.ijhydene.2008.07.098.

7. Claassen PAM, van Lier JB, Contreras AML, van Niel EWJ, Sijtsma L, Stams AJM, de Vries SS, Weusthuis RA. Utilisation of biomass for the supply of energy carriers. Appl Microbiol Biotechnol. 1999;52(6):741-55. https://doi. org/10.1007/s002530051586.

8. Hamelinck CN, van Hooijdonk G, Faaij APC. Ethanol from lignocellulosic biomass: techno-economic performance in short-, middle- and longterm. Biomass Bioenergy. 2005;28(4):384-410. https://doi.org/10.1016/j. biombioe.2004.09.002.

9. Kengen SWM, Goorissen HP, Verhaart M, Stams AJM, van Niel EWJ, Claassen PAM. Biological hydrogen production by anaerobic microorganisms. In: Soetaert W, Vandamme EJ, editors. Biofuels. Chichester: Wiley; 2009. p. 197-221.

10. Willquist K, Zeidan AA, van Niel EWJ. Physiological characteristics of the extreme thermophile Caldicellulosiruptor saccharolyticus: an efficient hydrogen cell factory. Microb Cell Fact. 2010;9:89. https://doi. org/10.1186/1475-2859-9-89.

11. Thauer RK, Jungermann K, Decker K. Energy conservation in chemotrophic anaerobic bacteria. Bacteriol Rev. 1977;41(1):100-80.

12. Rainey FA, Donnison AM, Janssen PH, Saul D, Rodrigo A, Bergquist $\mathrm{PL}$, et al. Description of Caldicellulosiruptor saccharolyticus gen. nov., 
sp. nov: an obligately anaerobic, extremely thermophilic, celluloIytic bacterium. FEMS Microbiol Lett. 1994;120(3):263-6. https://doi. org/10.1111/j.1574-6968.1994.tb07043.x.

13. van de Werken HJG, Verhaart MRA, VanFossen AL, Willquist K, Lewis DL, Nichols JD, Goorissen HP, Mongodin EF, Nelson KE, van Niel EWJ, et al. Hydrogenomics of the extremely thermophilic bacterium Caldicellulosiruptor saccharolyticus. Appl Environ Microbiol. 2008;74(21):6720-9. https ://doi.org/10.1128/AEM.00968-08.

14. VanFossen AL, Verhaart MRA, Kengen SMW, Kelly RM. Carbohydrate utilization patterns for the extremely thermophilic bacterium Caldicellulosiruptor saccharolyticus reveal broad growth substrate preferences. Appl Environ Microbiol. 2009;75(24):7718-24. https://doi.org/10.1128/ AEM.01959-09.

15. Ljunggren $M$, Willquist $K$, Zacchi $G$, van Niel EW. A kinetic model for quantitative evaluation of the effect of hydrogen and osmolarity on hydrogen production by Caldicellulosiruptor saccharolyticus. Biotechnol Biofuels. 2011:4:31. https://doi.org/10.1186/1754-6834-4-31.

16. Auria R, Boileau C, Davidson S, Casalot L, Christen P, Liebgott PP, CombetBlanc Y. Hydrogen production by the hyperthermophilic bacterium Thermotoga maritima Part II: modeling and experimental approaches for hydrogen production. Biotechnol Biofuels. 2016;9:268. https://doi. org/10.1186/s13068-016-0681-0.

17. Monod J. Recherches sur la croissance des cultures bactériennes. Ph.D. thesis, Université de Paris, Hermann, Paris. 1941.

18. Kompala DS, Ramkrishna D, Jansen NB, Tsao GT. Investigation of bacterial growth on mixed substrates: experimental evaluation of cybernetic models. Biotechnol Bioeng. 1986;28:1044-55. https://doi.org/10.1002/ bit.260280715.

19. Boianelli A, Bidossi A, Gualdi L, Mulas L, Mocenni C, Pozzi G, Vicino A Oggioni MR. A non-linear deterministic model for regulation of diauxic lag on cellobiose by the pneumococcal multidomain transcriptional regulator CelR. PLoS ONE. 2012;7:10. https://doi.org/10.1371/journ al.pone.0047393.

20. Willquist K, van Niel EWJ. Growth and hydrogen production characteristics of Caldicellulosiruptor saccharolyticus on chemically defined minimal media. Int J Hydrogen Energy. 2012;37(6):4925-9. https://doi. org/10.1016/j.ijhydene.2011.12.055.

21. Zeidan AA, van Niel EWJ. A quantitative analysis of hydrogen production efficiency of the extreme thermophile Caldicellulosiruptor owensensis $\mathrm{OL}^{\top}$. Int J Hydrogen Energy. 2010;35(3):1128-37. https://doi.org/10.1016/j.ijhyd ene.2009.11.082.

22. Batstone DJ, Keller J, Angelidaki I, Kalyuzhnyi SV, Pavlostathis SG, Rozzi A Sanders WTM, Siegrist H, Vavilin VA. Anaerobic Digestion Model No. 1 IWA task group for mathematical modelling of anaerobic digestion processes. London: IWA Publishing; 2002

23. de Vrije T, Mars AE, Budde MA, Lai MH, Dijkema C, de Waard P, Claassen PAM. Glycolytic pathway and hydrogen yield studies of the extreme thermophile Caldicellulosiruptor saccharolyticus. Appl Microbiol Biotechnol. 2007;74(6):1358-67.
24. Swinnen IAM, Bernaerts K, Dens EJJ, Geeraerd AH, Van Impe JF. Predictive modelling of the microbial lag phase: a review. Int J Food Microbiol. 2004;94(2):137-59. https://doi.org/10.1016/.i.jfoodmicro.2004.01.006.

25. Hamby DM. A review of techniques for parameter sensitivity analysis of environmental models. Environ Monit Assess. 1994;32(2):135-54. https:// doi.org/10.1007/bf00547132.

26. Barrera EL, Spanjers H, Solon K, Amerlinck Y, Nopens I, Dewulf J. Modeling the anaerobic digestion of cane-molasses vinasse: extension of the Anaerobic Digestion Model No. 1 (ADM1) with sulfate reduction for a very high strength and sulfate rich wastewater. Water Res. 2015;71:42-54. https://doi.org/10.1016/j.watres.2014.12.026.

27. Pawar SS, Nkemka VN, Zeidan AA, Murto M, van Niel EWJ. Biohydrogen production from wheat straw hydrolysate using Caldicellulosiruptor saccharolyticus followed by biogas production in a two-step uncoupled process. Int J Hydrogen Energy. 2013;38(22):9121-30. https://doi. org/10.1016/j.jighdene.2013.05.075.

28. Roop Jl, Chang KC, Brem RB. Polygenic evolution of a sugar specialization trade-off in yeast. Nature. 2016;530:336-49. https://doi.org/10.1038/natur e16938.

29. Wang J, Atolia E, Hua B, Savir Y, Escalante-Chong R, Springer M. Natural variation in preparation for nutrient depletion reveals a cost-benefit tradeoff. PLoS Biol. 2015;13:1. https://doi.org/10.1371/journal.pbio.10020 41.

30. Kremling A, Geiselmann J, Ropers D, de Jong H. Understanding carbon catabolite repression in Escherichia coli using quantitative models. Trends Microbiol. 2015;23(2):99-109. https://doi.org/10.1016/j.tim.2014.11.002.

31. Deutscher J. The mechanisms of carbon catabolite repression in bacteria. Curr Opin Microbiol. 2008;11 (2):87-93. https://doi.org/10.1016/j. mib.2008.02.007.

32. Chu DF. In silico evolution of diauxic growth. BMC Evol Biol. 2015;15:211. https://doi.org/10.1186/s12862-015-0492-0.

33. Görke B, Stülke J. Carbon catabolite repression in bacteria: many ways to make the most out of nutrients. Nat Rev Microbiol. 2008;6(8):613-24. https://doi.org/10.1038/nrmicro1932.

34. Shen $N$, Zhang F, Song XN, Wang YS, Zeng RJ. Why is the ratio of H2/acetate over 2 in glucose fermentation by Caldicellulosiruptor saccharolyticus? Int J Hydrogen Energy. 2013;38(26):11241-7. https://doi.org/10.1016/j. ijhydene.2013.06.091.

35. Tartakovsky B, Mu SJ, Zeng Y, Lou SJ, Guiot SR, Wu P. Anaerobic Digestion Model No. 1-based distributed parameter model of an anaerobic reactor: II. Model validation. Bioresour Technol. 2008;99(9):3676-84. https://doi. org/10.1016/.j.biortech.2007.07.061.

36. Willquist K. Physiology of Caldicellulosiruptor saccharolyticus: a hydrogen cell factory. Ph.D. thesis, Lund University, Sweden. 2010

37. Song HS, Liu C. Dynamic metabolic modeling of denitrifying bacterial growth: the cybernetic approach. Ind Eng Chem Res. 2015;54(42):102217. https://doi.org/10.1021/acs.iecr.5b01615.

\footnotetext{
Ready to submit your research? Choose BMC and benefit from:

- fast, convenient online submission

- thorough peer review by experienced researchers in your field

- rapid publication on acceptance

- support for research data, including large and complex data types

- gold Open Access which fosters wider collaboration and increased citations

- maximum visibility for your research: over 100M website views per year
}

At BMC, research is always in progress.

Learn more biomedcentral.com/submissions 